[Review Paper]

\title{
Application of Computer Graphics and Molecular Dynamics to the Investigation of Heterogeneous Catalysis
}

\author{
Akira Miчamoтo* and Momoji Kubo \\ Dept. of Molecular Chemistry and Engineering, Faculty of Engineering, \\ Tohoku University, Aoba-ku, Sendai 980
}

(Received November 26, 1992)

\begin{abstract}
The application of computer graphics (CG) and molecular dynamics (MD) to the investigation of structures and functions of heterogeneous catalysts was demonstrated to display the deposition and sintering of ultrafine metal particles on matal oxide support. The Au atoms in the Au cluster moved considerably with time even at $300 \mathrm{~K}$, and the movement of atoms became more evident with rise in temperature. In agreement with the mobility of Au cluster and $\mathrm{MgO}$ (100) plane, the shape of Au cluster changed significantly during the deposition process of Au cluster on $\mathrm{MgO}$ (100) plane, while the position of $\mathrm{Mg}$ and $\mathrm{O}$ ions at $\mathrm{MgO}$ (100) plane did not change appreciably. The shape of Au cluster after the deposition also changed markedly by the interaction potentials between $\mathrm{Au}$ and $\mathrm{MgO}$. The sintering process of two Au clusters attached on $\mathrm{MgO}$ (100) plane was satisfactorily simulated, suggesting that the MD and CG are useful for investigating the deactivation mechanism of supported metal catalysts which are important in relation to the automotive exhaust gas control. The MD and CG methods were also applied to the molecular sieving effect of A-type zeolites in the diffusion and separation of $\mathrm{O}_{2}$ and $\mathrm{N}_{2}$. For $\mathrm{CaNaA}$ zeolite having the open 8-membered ring window, both $\mathrm{N}_{2}$ and $\mathrm{O}_{2}$ molecules moved freely through the window. For $\mathrm{NaA}$ zeolite having $\mathrm{Na}^{+}$ions at the window, the diffusion behavior changed greatly, affected by the kind of molecule structure and temperature. At higher temperatures, both $\mathrm{N}_{2}$ and $\mathrm{O}_{2}$ are caused to migrate through the window. At lower temperatures, the separation of $\mathrm{O}_{2}$ and $\mathrm{N}_{2}$ was simulated and dynamically visualized. The mobility of $\mathrm{Na}^{+}$cation at the window was found to be the cause for the significant difference in the molecular sieving effect of $\mathrm{NaA}$, at different temperatures. MD and CG were applied to investigate the role of zeolite framework in the direct decomposition of NO to $\mathrm{N}_{2}$ and $\mathrm{O}_{2}$ on $\mathrm{Cu}-\mathrm{ZSM}-5$ catalysts. On the basis of the calculated results for various states of $\mathrm{Cu}^{+}$and $\mathrm{Cu}^{2+}$ ions in ZSM-5, the relative stability of $\mathrm{Cu}^{+}$to $\mathrm{Cu}^{2+}$ in ZSM-5 was found to provide one of the reasons for the high activity of $\mathrm{Cu}-\mathrm{ZSM}-5$. By calculation, increase in $\mathrm{Si} / \mathrm{Al}$ ratio in $\mathrm{Cu}-\mathrm{ZSM}-5$ would be favorable for the reaction, which is in agreement with experiments.
\end{abstract}

\section{Introduction}

Much attention has recently been given to “Computer Assisted Material Design" employing such methods as quantum mechanics, molecular dynamics (MD), molecular mechanics, artificial intelligence, data-base, and computer graphics $(\mathrm{CG})^{1}$. By using MD and CG, we previously investigated structures and functions of various materials including catalytic materials, zeolitic materials, molecular sieving effects, surface and interface, ultrafine particles, heteroepitaxy and homoepitaxy, oxide superconductor films, magnetic materials, adsorption and catalysis, alkalimetal-doped $\mathrm{C}_{60}$, and supercritical fluid extraction. In the present paper, we describe results for (i) the deposition and sintering of ultrafine metal

\footnotetext{
* To whom correspondence should be addressed.
}

particles on metal oxide support, (ii) molecular sieving effect of zeolites, and (iii) role of zeolite framework in the decomposition of $\mathrm{NO}$ to $\mathrm{N}_{2}$ and $\mathrm{O}_{2}$ on $\mathrm{Cu}-\mathrm{ZSM}-5$. The behavior of ultrafine metal particles on metal oxide surfaces is important in relation to heterogeneous catalysis and metal-ceramic heterojunctions in advanced materials ${ }^{2 \sim 6)}$. Although much important information was experimentally obtained for the behavior of ultrafine metal particles on metal oxides $^{5), 6)}$, a theoretical approach would also be interesting to understand the dynamic behavior of metal clusters on the metal oxide ${ }^{6) \sim 8}$. Molecular sieving effect of zeolites applied to the separation of $\mathrm{O}_{2}$ and $\mathrm{N}_{2}$ in air is one of the highly significant topics of investigations in the field of zeolites. For example, Breck et al.9) observed the molecular sieving effect of $\mathrm{O}_{2}$ and $\mathrm{N}_{2}$ on $\mathrm{NaA}$ zeolite. Although equilibrium adsorption was observed at 
higher temperatures, the selective adsorption of $\mathrm{O}_{2}$ with a smaller radius was found at lower temperatures. In addition to a number of interesting experimental approaches, it would be interesting to apply theoretical methods to the subject, for atomistic understanding of the separation mechanism and for scientific design of separation materials ${ }^{10}$. The direct decomposition of $\mathrm{NO}$ to $\mathrm{N}_{2}$ and $\mathrm{O}_{2}$ is highly important in relation to catalytic processes in the realm of environmental protection. It was found that $\mathrm{Cu}-\mathrm{ZSM}-5$ performs the best for the reaction among various zeolites examined ${ }^{11)}$. It was also suggested that the reaction proceeds in a cycle of reductionoxidation between $\mathrm{Cu}^{+}$and $\mathrm{Cu}^{2+}$ and that the excellent performance of $\mathrm{Cu}-\mathrm{ZSM}-5$ is brought about by the easier desorption of $\mathrm{O}_{2}$ from the oxidized state, which is attributed to the easier conversion of $\mathrm{Cu}^{2+}$ to $\mathrm{Cu}^{+}$.

\section{Methods}

The MD calculation was made with XDORTO program developed by Kawamura ${ }^{12)}$. The Verlet algorithm was used for the calculation of atom motion, while the Ewald method was applied to the calculation of electrostatic interactions. The calculation was made for 1,000-10,000 steps with the time step of $2.5 \times 10^{-15} \mathrm{~s}$. The two-body, central force interatomic potential, Eq. (1), was used for all calculations. In Eq. (1), the first, second, and third terms refer to Coulomb, exchange repulsion, and Morse interactions, respectively.

$$
\begin{gathered}
u\left(r_{\mathrm{ij}}\right)=Z_{\mathrm{i}} Z_{\mathrm{j}} e^{2 / r_{\mathrm{ij}}}+f_{\mathrm{o}}\left(b_{\mathrm{i}}+b_{\mathrm{j}}\right) \exp \left(\left(a_{\mathrm{i}}+a_{\mathrm{j}}-r_{\mathrm{ij}}\right) /\left(b_{\mathrm{i}}+b_{\mathrm{j}}\right)\right) \\
+D_{\mathrm{ij}}\left(\exp \left(-2 \beta_{\mathrm{ij}}\left(r_{\mathrm{ij}}-r_{\mathrm{ij}}^{*}\right)\right)-2 \exp \left(-\beta_{\mathrm{ij}}\left(r_{\mathrm{ij}}-r_{\mathrm{ij}}^{*}\right)\right)\right)
\end{gathered}
$$

where $Z_{\mathrm{i}}$ is the atomic charge, $e$ the elementary electric charge, $r_{\mathrm{ij}}$ the interatomic distance, and $f_{\mathrm{o}}$ a constant. The parameters $a$ and $b$ in Eq. (1) represent the size and stiffness, respectively, in the exchange repulsion interaction, while $D_{\mathrm{ij}}, r_{\mathrm{ij}}^{*}$, and $\beta_{\mathrm{ij}}$ represent bond energy, equilibrium bond distance, and stiffness, respectively, in the Morse function. Calculations were made with a DEC Micro VAX II superminicomputer, OMRON LUNA88K workstation, Silicon Graphics IRIS-4D/TG25 workstation, and NEC PC-9801RA personal computer, while the visualization was made with Evans \& Sutherlands PS-390 three-dimensional color graphic terminal coupled with MOGLI software and IRIS-4D/TG-25 with Insight II software. The dynamic visualization was made with MOMOVIE program developed in our laboratory on OMRON LUNA-88K workstation.

\section{Results and Discussion}

\section{1. Deposition and Sintering Processes of Ultra- fine Metal Particles on Metal Oxide Sup- port ${ }^{7), 8)}$}

3. 1. 1. Structure and Dynamics of MgO (100) Plane, Au Crystal and Au Clusters

MD trajectories of ions on the MgO (100) plane were almost the same as those in bulk, in accordance with RHEED and LEED experiments ${ }^{13)}$. In other words, the surface structure of the $\mathrm{MgO}$ (100) plane does not change significantly from that of the MgO crystal.

According to MD calculations for the Au crystal, the trajectory of each atom was close to its average position determined by X-ray analysis ${ }^{14}$, indicating that the potential is effective for reproducing the structure of Au crystal. The calculated total energy was also consistent with the heat of vaporization of $\mathrm{Au}$.

The dynamics of ultrafine $\mathrm{Au}$ particles were investigated with the MD method for various numbers of atoms in the cluster. As an example, in Fig. 1 are shown CG pictures of an $\mathrm{Au}_{32}$ cluster after the MD calculation of various steps from the cubic $\mathrm{Au}_{32}$ cluster at $300 \mathrm{~K}$. Even at $300 \mathrm{~K}$, the shape of $\mathrm{Au}_{32}$ changes readily from cubic cluster to spherical cluster. The trajectory of each Au atom provided evidence for the dynamic behavior of $\mathrm{Au}$ atom in the cluster. This result is in contrast to the behavior of an Au crystal where the movement of Au is limited in the neighborhood of its average position. In other words, Au atoms in the cluster move much more dynamically than those in the crystal.

\section{1. 2. Sintering Process of $\mathbf{T w o} \mathrm{Au}_{32}$ Clusters on MgO (100) Plane}

The $\mathrm{Au}_{32}$ cluster was placed above the $\mathrm{MgO}$ (100) surface, and MD calculations were made for the combined system. On the basis of previous investigations of the metal-metal oxide interaction ${ }^{2), 3)}$, both $\mathrm{Au}-\mathrm{Mg}$ and $\mathrm{Au}-\mathrm{O}$ interactions were taken into consideration in the calculation. Because of the lack of detailed potential parameters for the $\mathrm{Au}-\mathrm{Mg}$ and $\mathrm{Au}-\mathrm{O}$ interactions ${ }^{6}$ ), calculations were made for various $D_{\mathrm{ij}}$ values of these interactions.

In Fig. 2 are shown $\mathrm{CG}$ pictures of an $\mathrm{Au}_{32}$ cluster on the $\mathrm{MgO}(100)$ plane after various steps of MD calculations. $\quad D_{\mathrm{ij}}$ for $\mathrm{Au}-\mathrm{Mg}$ and $\mathrm{Au}-\mathrm{O}$ was taken to be $2.24 \mathrm{kcal} / \mathrm{mol}, 20 \%$ of $D_{\mathrm{ij}}$ for the $\mathrm{Au}-\mathrm{Au}$ bond. When the $\mathrm{Au}_{32}$ cluster approaches the $\mathrm{MgO}$ (100) plane, Au atoms in the neighborhood of the $\mathrm{MgO}(100)$ surface are attracted to the $\mathrm{MgO}$ surface to deform the shape of the spherical cluster. 


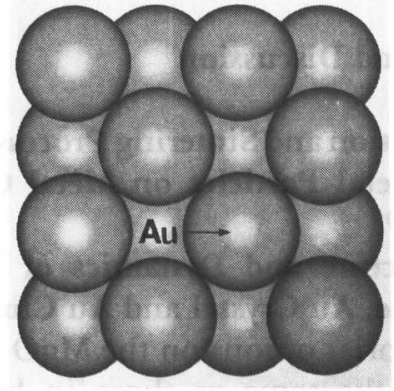

0 STEP

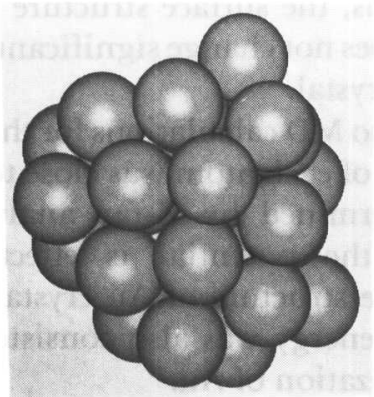

2000 STEP

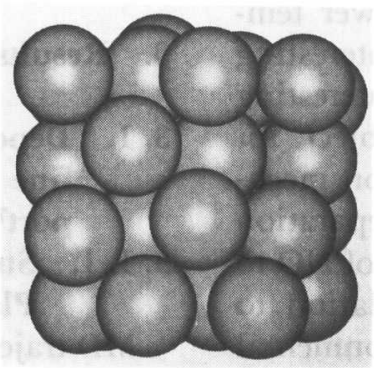

500 STEP

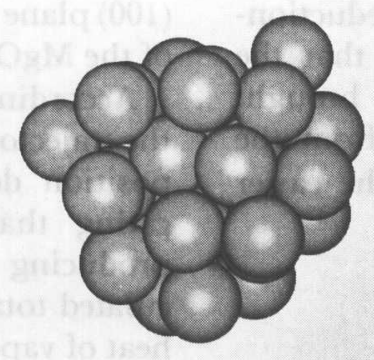

3000 STEP

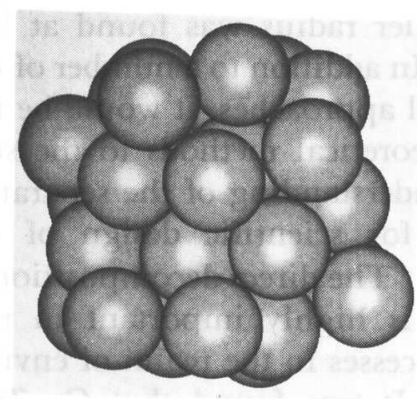

1000 STEP

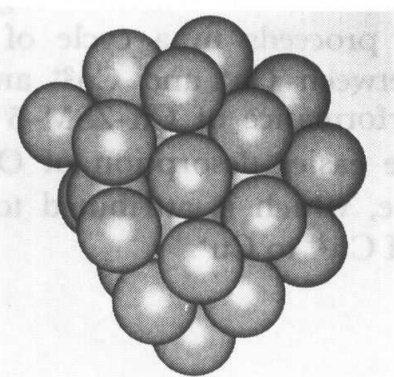

5000 STEP

$D_{\mathrm{ij}}=11.2 \mathrm{kcal} / \mathrm{mol}, r_{i j}^{*}=2.94 \AA$.

Fig. 1 CG Pictures of $\mathrm{Au}_{32}$ Clusters at Various Steps of MD Calculation at $300 \mathrm{~K}$

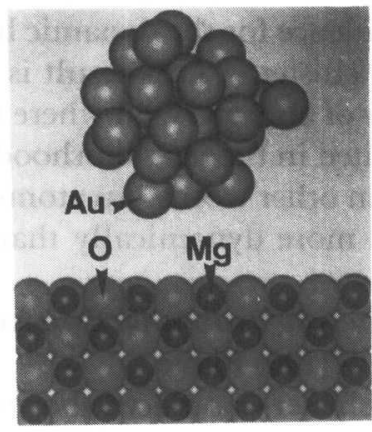

100 step

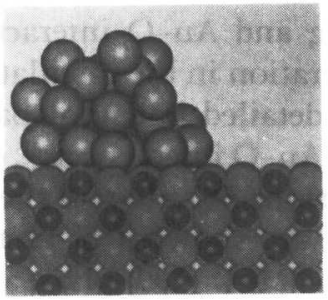

2000 step

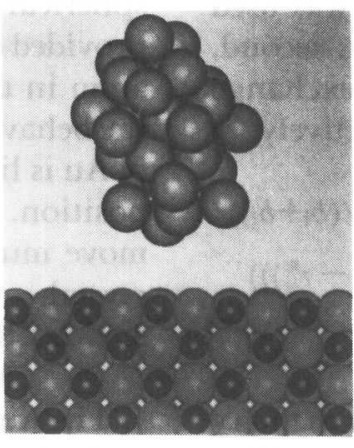

200 step

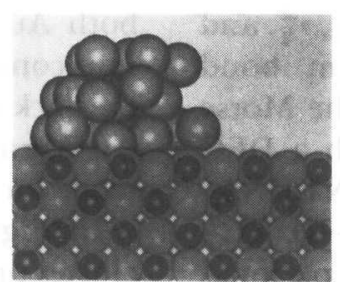

5000 step

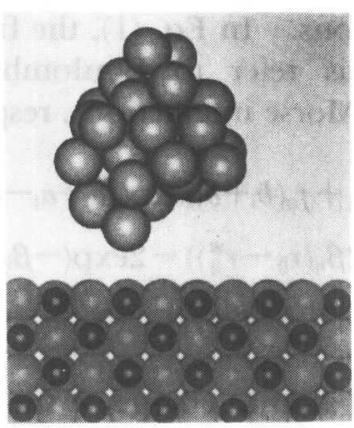

1000 step

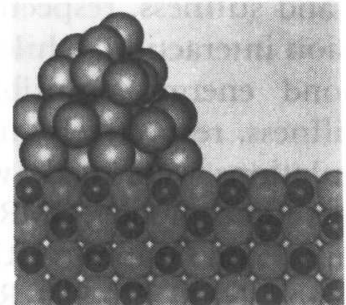

10000 step

$D_{i j}=2.24 \mathrm{kcal} / \mathrm{mol}$ for $\mathrm{Au}-\mathrm{O}$ and $\mathrm{Au}-\mathrm{Mg}$ interactions, $r_{i j}^{*}=2.30 \AA$ for $\mathrm{Au}-\mathrm{Mg}$ potential, $r_{i j}^{*}=2.70 \AA$ for $\mathrm{Au}-\mathrm{O}$ potential.

Fig. 2 Dynamic Processes of Fixation of $\mathrm{Au}_{32}$ Cluster on $\mathrm{MgO}$ (100) Plane at $300 \mathrm{~K}$ 


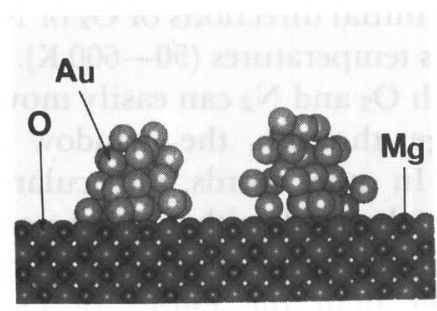

0 STEP

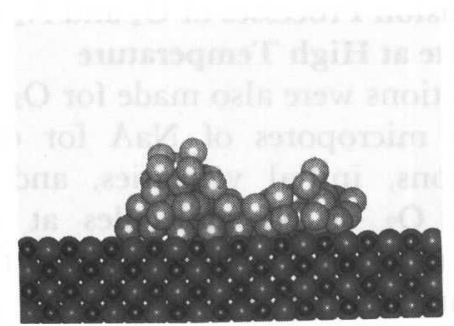

4000 STEP

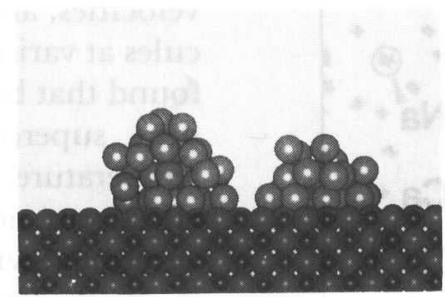

3000 STEP

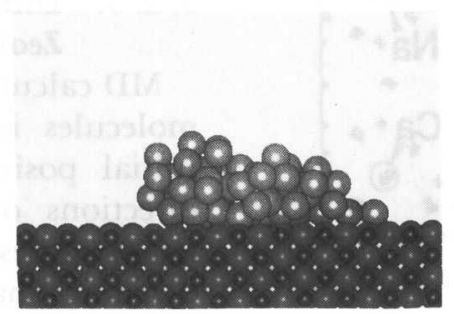

4500 STEP

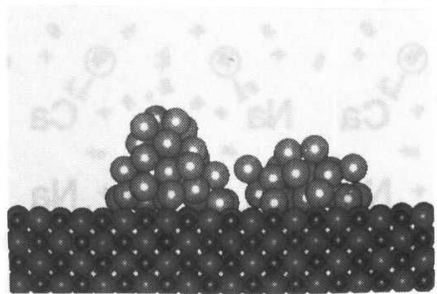

3500 STEP

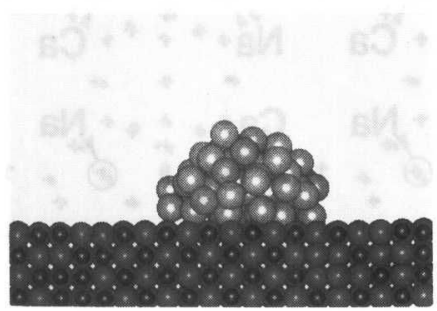

10000 STEP

$D_{\mathrm{ij}}=2.24 \mathrm{kcal} / \mathrm{mol}$ for $\mathrm{Au}-\mathrm{O}$ and $\mathrm{Au}-\mathrm{Mg}$ interactions, $r_{\mathrm{ij}}^{*}=2.30 \AA$ for $\mathrm{Au}-\mathrm{Mg}$ potential, $r_{\mathrm{ij}}^{*}=2.70 \AA$ for Au-O potential.

Fig. 3 Sintering Processes of Two Au 32 Clusters on MgO (100) Plane at $300 \mathrm{~K}$

The dynamic behavior of the Au cluster and further interaction with the $\mathrm{MgO}$ surface lead to the deposition of the $\mathrm{Au}_{32}$ cluster on the $\mathrm{MgO}$ (100) plane. At steps above 2,000, the shape of the cluster does not change significantly and remains hemispherical. In the deposition of the $\mathrm{Au}_{32}$ cluster, the geometry of the $\mathrm{MgO}$ (100) plane did not change markedly. This result is consistent with the behavior of the $\mathrm{MgO}$ (100) plane at various temperatures.

MD calculations for different values of $D_{\mathrm{ij}}$ indicated that the shape of the deposited metal cluster is a sensitive reflection of the interaction potential between the metal and metal oxide.

\section{1. 3. Sintering Process of $\mathbf{T}$ wo $\mathrm{Au}_{32}$ Clusters on} MgO (100) Plane

Much attention has been given to the mechanism for the deactivation of supported metal catalysts, and the sintering of ultrafine metal particles on a metal oxide support provides one of the most important causes for the catalyst deactivation. As a first step of atomistic investigations of sintering process of metal clusters on metal oxide support, the aggregation process of two $\mathrm{Au}_{32}$ clusters on $\mathrm{MgO}$ (100) plane was simulated by the MD method and the process was visualized by $\mathrm{CG}$.

In Fig. 3 are shown CG pictures of two $\mathrm{Au}_{32}$ clusters on $\mathrm{MgO}$ (100) plane after various steps of MD calculations at $300 \mathrm{~K}$. The interaction between two Aus2 clusters gradually deformed the cluster shape and finally aggregated to form a hemispherical $\mathrm{Au}_{64}$ cluster on $\mathrm{MgO}$ (100) plane. This indicates that the MD method is effective for simulating the sintering process of ultrafine metal particles on support and encourages further applications of the method to designing a catalytic system with a longer catalyst life.

\section{2. Diffusion and Separation Processes of $\mathbf{O}_{2}$} and $\mathrm{N}_{2}$ in $\mathrm{NaA}$ and CaNaA Zeolites ${ }^{10)}$

\section{2. 1. Structures of $\mathrm{CaNaA}$ and $\mathrm{NaA}$ Zeolites}

Before the application of the MD method to the separation process of $\mathrm{O}_{2}$ and $\mathrm{N}_{2}$, calculations were made for the $\mathrm{CaNaA}$ with a definite crystal structure $^{15)}$. Namely, the positions of $\mathrm{Al}, \mathrm{Si}, \mathrm{Na}$, $\mathrm{Ca}$, and $\mathrm{O}$ was determined experimentally by X-ray crystallographic analysis ${ }^{16)}$. As shown in Fig. 4, the trajectories of $\mathrm{Ca}, \mathrm{Na}, \mathrm{Al}, \mathrm{Si}$, and $\mathrm{O}$ atoms calculated by the MD method are close to those determined experimentally, indicating that the simple two-body interatomic potential (Eq. (1)) is effective for reproducing the CaNaA structure. Similar results were also obtained for $\mathrm{NaA}$ zeolite $^{17)}$, and $\mathrm{CG}$ pictures of $\mathrm{CaNaA}$ and $\mathrm{NaA}$ calculated by the MD method are shown in Fig. 5 .

The potential parameters for $\mathrm{O}_{2}$ and $\mathrm{N}_{2}$ molecules were also determined to reproduce the bond length, bond energy, and vibrational spectrum.

\section{2. 2. Diffusion Processes of $\mathrm{O}_{2}$ and $\mathbf{N}_{2}$ in} CaNaA Zeolite

Dynamic behavior of $\mathrm{O}_{2}$ and $\mathrm{N}_{2}$ molecules in micropores of $\mathrm{CaNaA}$ was calculated with the MD method for different initial positions, initial 


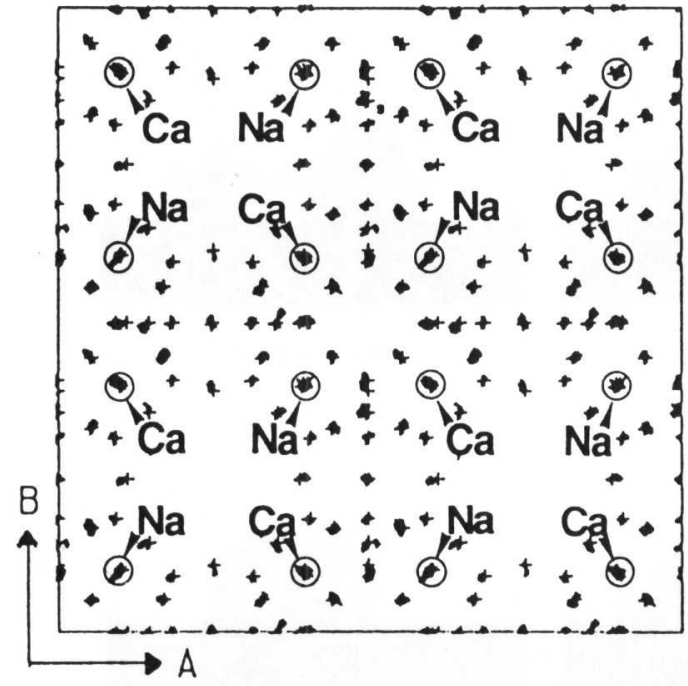

Calculated by the MD method at $600 \mathrm{~K}$ (solid line) and the average positions of atoms determined experimentally $(+)$.

Fig. 4 Trajectories of Atoms in CaNaA Zeolite

a

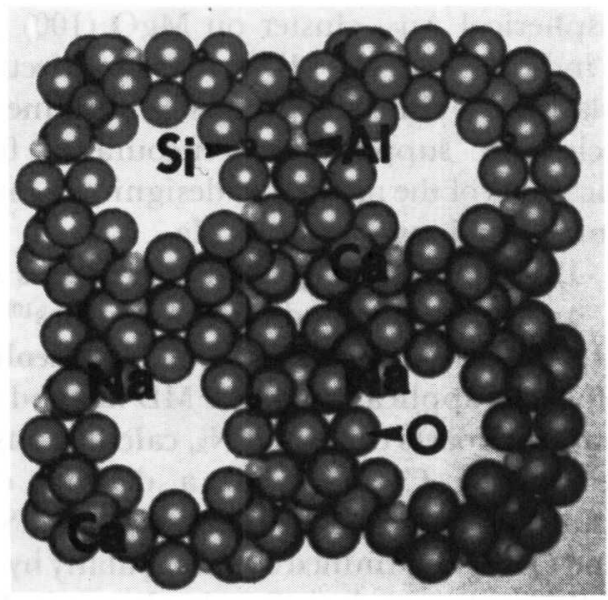

b

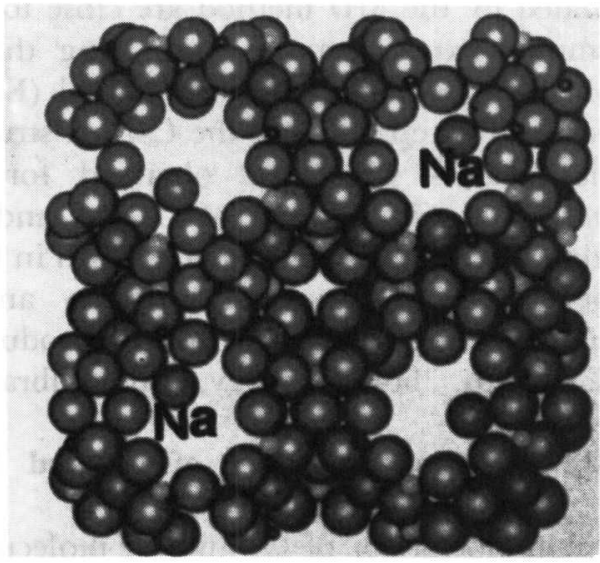

Fig. 5 CG Pictures of $\mathrm{CaNaA}$ (a) and $\mathrm{NaA}$ (b) Zeolites Calculated by MD Method velocities, and initial directions of $\mathrm{O}_{2}$ or $\mathrm{N}_{2}$ molecules at various temperatures $(50-600 \mathrm{~K})$. It was found that both $\mathrm{O}_{2}$ and $\mathrm{N}_{2}$ can easily move to the next supercage through the window at any temperature. In other words, molecular sieving effect was not observed with $\mathrm{CaNaA}$ zeolite, in agreement with the open 8-membered ring, which is much larger than the radius of $\mathrm{O}_{2}$ or $\mathrm{N}_{2}$ molecule.

3. 2. 3. Diffusion Processes of $\mathrm{O}_{2}$ and $\mathrm{N}_{2}$ in $\mathrm{NaA}$ Zeolite at High Temperature

MD calculations were also made for $\mathrm{O}_{2}$ and $\mathrm{N}_{2}$ molecules in micropores of $\mathrm{NaA}$ for different initial positions, initial velocities, and initial directions of $\mathrm{O}_{2}$ or $\mathrm{N}_{2}$ molecules at various temperatures $(50-600 \mathrm{~K})$. It was found that the dynamic characteristics of $\mathrm{O}_{2}$ and $\mathrm{N}_{2}$ change greatly, depending on temperature and structure of molecule. At a higher temperature such as $300 \mathrm{~K}$, both $\mathrm{O}_{2}$ and $\mathrm{N}_{2}$ can migrate through the space near $\mathrm{Na}^{+}$cation at the window (Fig. 6).

At a low temperature, such as $262 \mathrm{~K}$, the diffusion process of $\mathrm{O}_{2}$ at the window of $\mathrm{NaA}$ was greatly different from that of $\mathbf{N}_{2}$. In Fig. 7 are shown examples of diffusion processes of $\mathrm{O}_{2}$ and $\mathrm{N}_{2}$ in NaA zeolite at $262 \mathrm{~K}$. The initial velocity, position, and direction was common to both molecules. Although $\mathrm{O}_{2}$ molecules can migrate through the window to the next cage, a $\mathrm{N}_{2}$ molecule is repelled by the $\mathrm{Na}$ ion at the window and cannot diffuse to another cage. These results are consistent with experimental data obtained by Breck et al. ${ }^{9}$.

3. 2. 4. Role of $\mathrm{Na}^{+}$Ions at the Window in the Molecular Sieving Effect

The dynamic visualization of the diffusion process of $\mathrm{O}_{2}$ and $\mathrm{N}_{2}$ at different temperatures suggested that the mobility of $\mathrm{Na}^{+}$located at the window is important for any significant effect of temperatures on the molecular sieving effect.

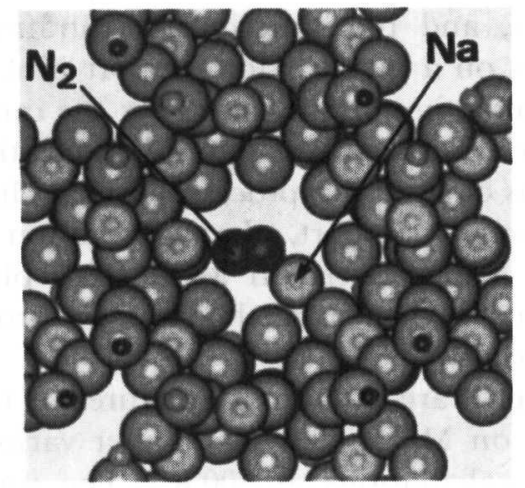

Fig. 6 CG Picture of $\mathrm{N}_{2}$ Molecule near the Window of NaA Zeolite at $300 \mathrm{~K}$ 


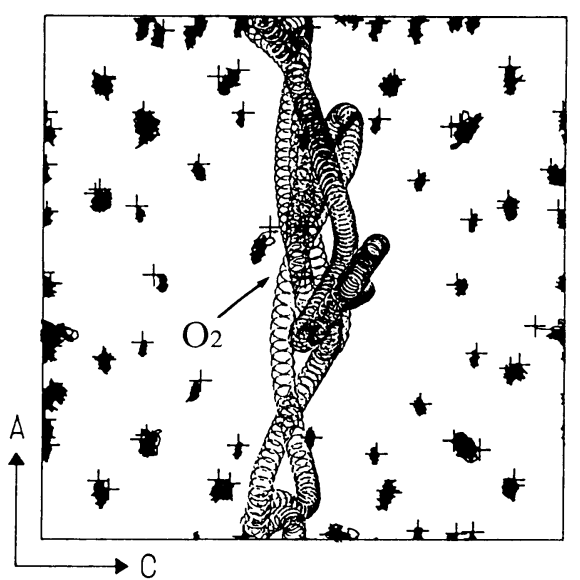

b

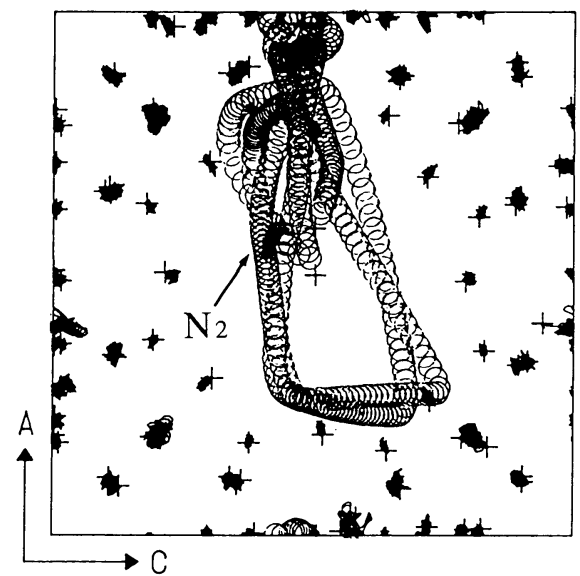

Fig. 7 Trajectories of $\mathrm{O}_{2}(\mathrm{a})$ and $\mathrm{N}_{2}$ (b) Molecules in NaA Zeolite at $262 \mathrm{~K}$

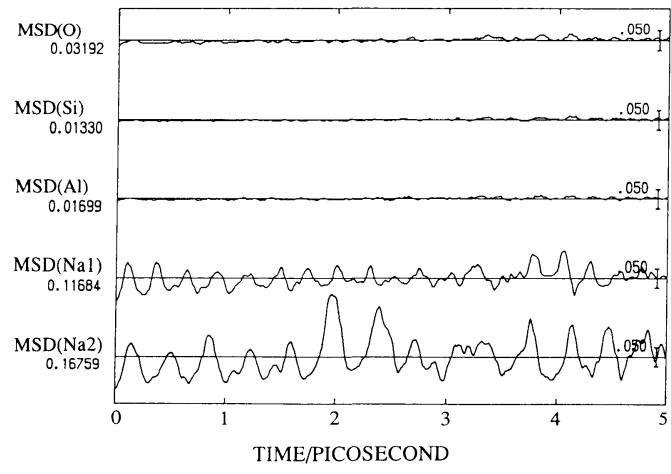

Fig. 8 Changes of Mean Square Displacements (MSD) of Various Atoms in NaA Zeolite at $300 \mathrm{~K}$

The dynamic behavior of $\mathrm{Na}^{+}$ions can be seen in the changes of mean square displacements (MSD) at various times of MD calculation. As shown in Fig. 8, MSD of $\mathrm{Na}$ ions located at the 8-membered ring ( $\mathrm{Na} 2)$ is much larger than that of $\mathrm{O}^{2-}, \mathrm{Si}^{4+}$, $\mathrm{Al}^{3+}$, or the other $\mathrm{Na}$ ions (Nal). In other words, the $\mathrm{Na}$ ion at the window is the most influential matter in determining the effective pore radius of the NaA. It was also found that MSD of $\mathrm{Na} 2$ increases with rise in temperature. Consequently, the significant effect of temperature on the molecular sieving effect of $\mathrm{NaA}$ can be understood in terms of the increased mobility of the $\mathrm{Na}^{+}$ion at the window at higher temperatures.

3. 3. Role of Zeolite Framework in Cu-Ionexchanged Zeolites for the Decomposition of NO

3. 3. 1. Structure and Dynamics of ZSM-5 without Al Incorporation

It was demonstrated that the simple two-body interatomic potential such as Eq. (1) is effective for reproducing the structure of ZSM-5. In Fig. 9

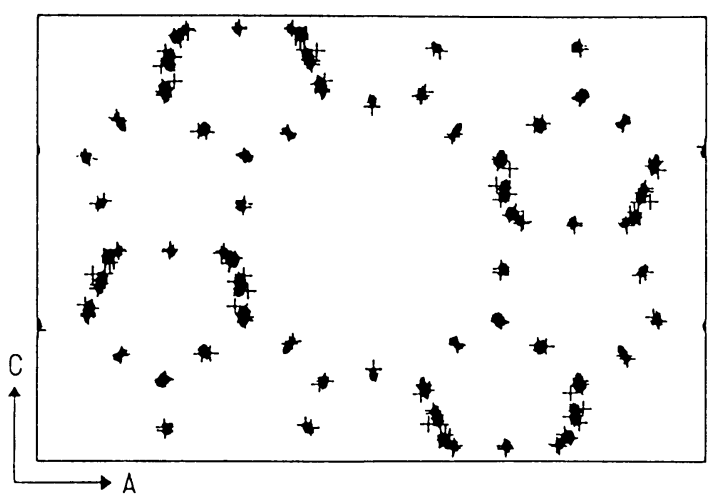

Calculated with the MD method at $600 \mathrm{~K}$ (solid line) and average positions determined experimentally $(+)$.

Fig. 9 Trajectories of Atoms in 7SM-5 without Al Incorporation

is shown an example of MD calculations for ZSM-5 without Al incorporation. The trajectories of $\mathrm{Si}$ and $\mathrm{O}$ atoms calculated with the MD method are close to the average positions of the ions determined by the X-ray analysis ${ }^{17)}$. Under the condition, the mean square displacement of ions from the position of the $\mathrm{X}$-ray analysis were $0.103 \AA^{2}$ for the $\mathrm{O}^{2-}$ ion, while $0.039 \AA^{2}$ for the $\mathrm{Si}^{4+}$ ion. These values are not significant in comparison of the temperature factor in the $\mathrm{X}$ ray crystal structure analysis. Consequently, the micropore structure of ZSM-5 was reproduced by using the MD method with the interatomic potential of Eq. (1).

\section{3. 2. Structure and Dynamics of $\mathrm{Cu}^{+}$Ions in ZSM-5}

The decomposition of $\mathrm{NO}$ to $\mathrm{N}_{2}$ and $\mathrm{O}_{2}$ on $\mathrm{Cu}-\mathrm{ZSM}-5$ is considered to proceed by the redox 
cycle between $\mathrm{Cu}^{+}$and $\mathrm{Cu}^{2+11)}$. Thus, the structures and dynamics of $\mathrm{Cu}^{+}$and $\mathrm{Cu}^{2+}$ ions in ZSM-5 were calculated with the MD method. In ionexchanged ZSM-5, the position of ion-exchanged cation has not necessarily been determined exactly, although a quantum chemical calculation suggests that $\mathrm{Al}$ ion is located at the $\mathrm{T} 12$ sites among the 12 possible sites of $\mathrm{T}$ atoms ${ }^{19)}$. Thus, a part of the $8 \mathrm{Si}$ atoms in the $\mathrm{T} 12$ site was replaced with $\mathrm{Al}$ atoms, and MD calculations were made for different initial position of $\mathrm{Cu}^{+}$cation to investigate the structure and dynamics of the cation. When the initial position was close to the possible position of the ion-exchange site in the neighbor of $\mathrm{Al}^{3+}$, the ion migrated readily to the position. When the initial position was far from the ion-exchange site, it was necessary to raise the temperature for the ion to migrate to the cited position. In Fig. 10 is shown an example for two $\mathrm{Al}^{3+}$, namely two $\mathrm{Cu}^{+}$ions, in a unit cell of ZSM-5. Both $\mathrm{Cu}^{2+}$ ions can migrate easily at $600 \mathrm{~K}$ to the ion-exchange site in the vicinity of $\mathrm{Al}^{3+}$. Similar results were also obtained for more or less quantity of $\mathrm{Al}^{3+}$ in the unit cell. As an example, in Fig. 11

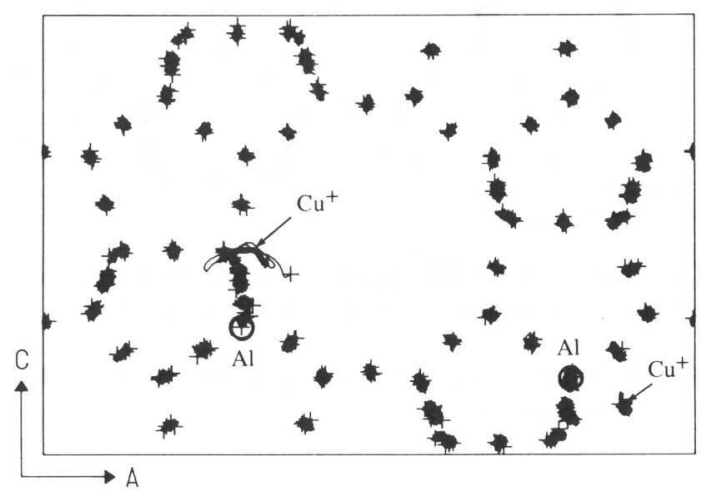

Fig. 10 Trajectories of Atoms in Cu-ZSM-5 with Two $\mathrm{Cu}^{+}$Ions in the Unit Cell at $600 \mathrm{~K}$

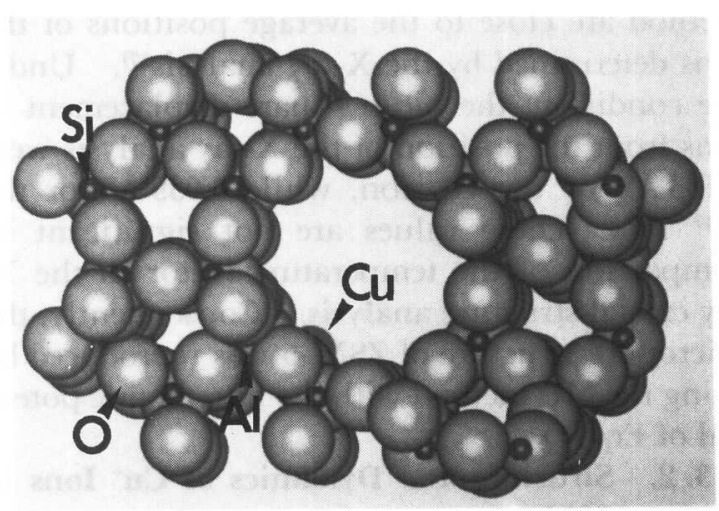

Fig. Il CG Picture of Cu-ZSM-5 with a $\mathrm{Cu}^{+}$Ion in the Unit Cell at $600 \mathrm{~K}$ is shown a CG picture of the final structure of $\mathrm{Cu}^{+}$ in $\mathrm{Cu}-\mathrm{ZSM}-5$ with a $\mathrm{Cu}^{+}$ion in the unit cell.

3.3.3. Structure and Dynamics of $\mathrm{Cu}^{2+}$ Ions in ZSM-5

At lower temperatures, $\mathrm{Cu}^{2+}$ ion in Cu-ZSM-5 is considered to be in $\mathrm{Cu}^{2+} \mathrm{OH}^{-}$state. However, at elevated temperatures, the $\mathrm{Cu}^{2+} \mathrm{OH}^{-}$species is considered to be dehydrated:

$$
\mathrm{Cu}^{2+} \mathrm{OH}^{-} \longrightarrow \mathrm{Cu}^{2+}+\mathrm{Cu}^{2+} \mathrm{O}^{2-}+\mathrm{H}_{2} \mathrm{O} \text {. }
$$

Thus, the structures and dynamics of $\mathrm{Cu}^{2+}$ and $\mathrm{Cu}^{2+} \mathrm{O}^{2-}$ species were simulated and an example of the calculated trajectories is shown in Fig. 12. Both $\mathrm{Cu}^{2+}$ and $\mathrm{Cu}^{2+} \mathrm{O}^{2-}$ species are located at the ion-exchange site in the vicinity of $\mathrm{Al}^{3+}$, and $\mathrm{O}^{2-}$ in $\mathrm{Cu}^{2+} \mathrm{O}^{2-}$ does not migrate to another $\mathrm{Cu}^{2+}$ species. Similar results were also obtained for different distributions of $\mathrm{Al}^{3+}$ in $\mathrm{T} 12$ site.

3. 3. 4. Relative Stability of $\mathrm{Cu}^{2+}$ and $\mathrm{Cu}^{+}$Species in ZSM-5

The mobility of each $\mathrm{Cu}^{+}$ion is limited near the $\mathrm{Al}^{3^{+}}$ion (Figs. 10 and 11). This means that the negative charge around $\mathrm{AlO}_{2}^{-}$is locally neutralized by the positive charge of $\mathrm{Cu}^{+}$ion in $\mathrm{Cu}-\mathrm{ZSM}-5$. On the other hand, $\mathrm{Cu}^{2+}$ species at the ionexchange site forms a net positive charge while $\mathrm{Cu}^{2+} \mathrm{O}^{2-}$ species cannot neutralize the negative charge around $\mathrm{AlO}_{2}^{-}$(Fig. 12). This results in the separated positive and negative charges in the ZSM-5 crystal for $\mathrm{Cu}^{2+}$ state. As shown in the relationship between the Coulomb energy and the distance between positive and negative charges (Fig. 13), their separation significantly increase the electrostatic energy, thus decreasing the stability of $\mathrm{Cu}^{2+}$ state.

3. 3. 5. Influence of Structure on the High Activity of ZSM-5 for the Decomposition of NO

The $\mathrm{Si} / \mathrm{Al}$ ratio of ZSM-5 is usually higher than

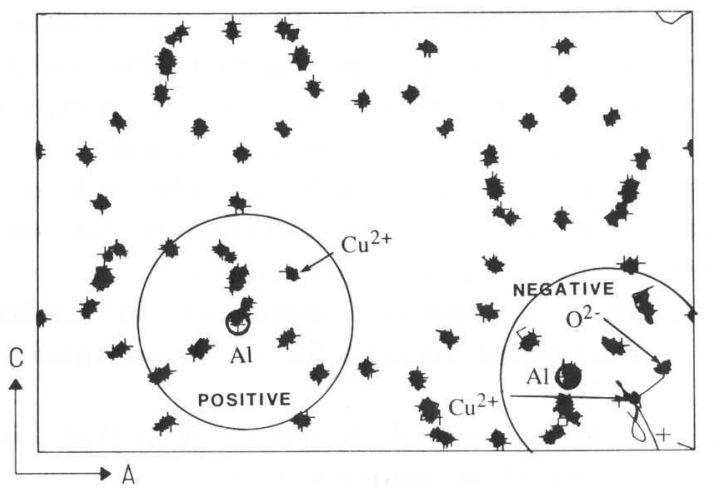

Fig. 12 Trajectories of Atoms in Cu-ZSM-5 with Two $\mathrm{Cu}^{2+}$ Ions $\left(\mathrm{Cu}^{2+}\right.$ and $\left.\mathrm{Cu}^{2+} \mathrm{O}^{2-}\right)$ in the Unit Cell at $600 \mathrm{~K}$ 


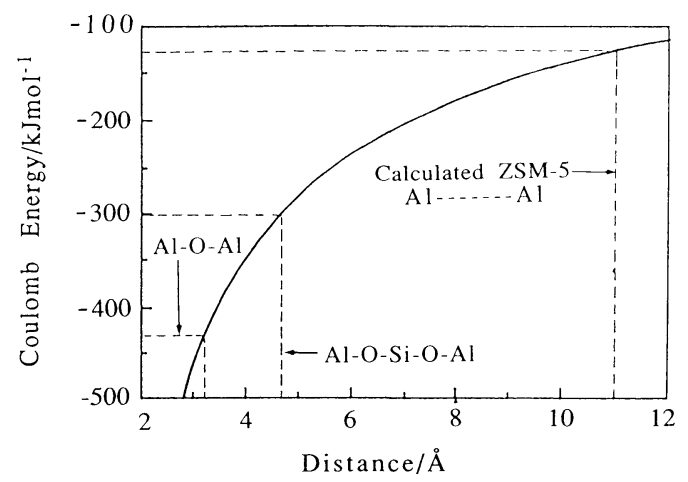

Fig. 13 The Coulomb Energy against the Distance between Positive and Negative Charges

that of other zeolites, indicating that the average distance between ion-exchange sites in ZSM-5 is greater than that in the other zeolite. The electrostatic instability of $\mathrm{Cu}^{2+}$ state is increased with increase in distance, suggesting that the stability of $\mathrm{Cu}^{+}$relative to $\mathrm{Cu}^{2+}$ for ZSM-5 is higher than that for the other zeolite (Fig. 13). Further, the desorption of $\mathrm{O}_{2}$ from the oxidized state $\left(\mathrm{Cu}^{2+}\right)$ to the reduced state $\left(\mathrm{Cu}^{+}\right)$is considered to be the key step in the decomposition of $\mathrm{NO}$ to $\mathrm{N}_{2}$ and $\mathrm{O}_{2}$. The above-mentioned conclusion, therefore, is consistent with experimental results in regard to higher activity of $\mathrm{Cu}-\mathrm{ZSM}-5$ for the decomposition of NO compared to the other zeolite, and the increase in specific activity of $\mathrm{Cu}$ ion with increase of $\mathrm{Si} / \mathrm{Al}$ ratio in $\mathrm{Cu}-\mathrm{ZSM}-5^{11}$.

\section{References}

1) Niiyama, II., I Iattori, T., Miyamoto, A., Catal. Today, 10. (1991).

2) Miyamoto, A., Inui, T., Catal. Today, 10, 201 (1991).

3) Miyamoto, A., Haruta, M., Inui, T., Catal. Sci. Technol., 1. 497 (1991).

4) Haruta, M., Kobayashi, T., Iijima, S., Delannay, F., Proc. 9th Intern. Congr. Catal., (1988), 3, p. 1206; Iaruta, M., Kageyama, II., Kamijo, N., Kobayashi, T., Delannay, F. Stud. Surf. Sci. Catal., 44, 33 (1989).

5) Nagao, M., Tanaka, N., Mihama, K., Jpn. J. Appl. Phys., 25, L.215 (1986).

6) Ohuchi, F. S., Kohyama, M., J. Am. Ceram. Soc., 74, 1163 (1991) and references therein.

7) Miyamoto, A., Hattori, T., Inui, T., Appl. Surf. Sci., 60, 660 (1992).

8) Miyamoto, A., Hattori, T., Kubo, M., Inui, T., Proc. 2nd Int. Conf. Appl. Mater. Mol. Sci. Eng., 1021 (1993).

9) Breck, D. W., Smith, J. V., Sci. Am., 200, 85 (1959).

10) Kubo, M., Miyamoto, A., Proc. 2nd Int. Conf. Appl. Mater. Mol. Sci. Eng., 295 (1993).

11) Iwamoto, M., "Chemistry of Microporous Crystals", eds. by Inui, T. et al., Kodansha, Tokyo (1991), p. 327.

12) Kawamura, K., "Introduction to Molecular Simulations". eds. by Okada, I., Osawa, E., Kaibundo, Tokyo (1989), chs. 7 and 8 .

13) Ienrich, V. E., Rep. Prog. Phys., 48, 1481 (1985).

14) "Crystal Structure", Vol. 1, ed. by Wyckoff, R. W'. G. Interscience Pub., New York (1963).

15) Miyamoto, A., Matsuba, M., Kubo, M., Kawamura, K.. Inui, T., Chem. Lett., 2055 (1991).

16) Broussard, I.., Shoemaker, D. P., J. Am. Chem. Soc., 82, 1041 (1960).

17) Yanagida, R. Y., Amaro, A. A., Seff, K., J. Phys. Chem., 77. 805 (1970)

18) Olson, D. H., Kokotailo, G. T., Iawton, S. I ... Meier, W'. M., J. Phys. Chem., 85, 2238 (1981).

19) Fripat, J. G., Berger-Andre, F., Derouane, F. (;., Zeolite, 3. 306 ( 1983$)$. 
要旨

\section{コンピューターグラフィックスと分子動力学法による固体触媒の研究}

宮本 明，久保百司

東北大学工学部, 980 仙台市青葉区荒巻字青葉

近年，量子化学，分子動力学（MD）法，分子力学法，人「 知能, データベース, コンピューターグラフィックス (CG) などの手法を利用した，コンピューターによる材料設計に対す る期待が高まってきている。著者らは MD 法と CG を活用 し，触媒劣化との関連で興味深い金属酸化物担体上の金属超微 粒子のシンタリング過程の詳細を明らかにし，MD 法と CG を用いた分子設計が触媒材料開発に有効であることを示した。 $\mathrm{A}$ 型ゼオライトによる $\mathrm{N}_{2}, \mathrm{O}_{2}$ 分離機構についても検討を行 い, $\mathrm{NaA}$ 型ゼオライトにおいては系の温度と分子構造の相違
により分子の拡散挙動が大きく異なること，さらには $\mathrm{NaA}$ 型 ゼオライトの 8 員環細孔を部分的にふさいでいる $\mathrm{Na}^{+}$のダイ ナミックな挙動が，分子ふるい作用に重要な役割を果たすこと を明らかにした。自動車排ガス浄化触媒として注目されている Cu-ZSM-5 の NO 還元特性についても検討し, $\mathrm{Cu}-\mathrm{ZSM}-5$ 中 では $\mathrm{Cu}^{2+}$ が $\mathrm{Cu}{ }^{+}$に比べて安定に存在することが, Cu-ZSM-5 の高い NO 還元特性の理由の一つであること, さ らには $\mathrm{Cu}-\mathrm{ZSM}-5$ 中の $\mathrm{Si} / \mathrm{Al}$ 比が増加するとともに, Cu-ZSM-5 の NO 分解性能が向上することを明らかにした。

\section{Keywords}

Adsorption, Zeolite, Supported catalyst, Metal catalyst, Molecular design, Computer graphics 